\title{
Rice Bran as a Functional Food for Elderly in Egypt
}

\author{
Doaa A. A.AbdelBary \\ Rice Technology Training Center, Field Crops Research Institute, Agricultural Research Center
}

\begin{abstract}
The bran, which is an important by-product obtained during rice milling, amount to be around $1 / 10$ of the weight of rice grain. Rice bran is the most outer part of the cargo rice including the embryo (Germ) that is removed during the rice process to produce white rice. This bran is reported to be high in natural vitamins and minerals, particularly vitamin E. The current study is designed to prepare cookies from stabilized rice bran that could prevent many diseases and evaluate health properties by consuming a quality of cookies. The main objectives of this research were to evaluate the suitability of Microwave stabilized rice bran (MSRB) and Oven heat stabilized rice bran (OSRB) supplemented cookies and to bake and test the rice bran supplemented cookies for the chemical, physical and sensory evaluation. Freshly milled bran was treated with heat by placing it in a Microwave for 3 minutes to get MSRB. Whereas to prepare OSRB, the rice bran was placed in an oven, maintained at a temperature of $120{ }^{\circ} \mathrm{C}$ for 10 to 15 seconds. The cookies were prepared by supplementing rice bran in wheat flour at $0,5,10,15$ and 25 percent level respectively. Chemical analysis, minerals determination, physical and sensory evaluation were conducted on all cookies samples. Results revealed that small to moderate inclusion levels of rice bran, especially in the range of 10 to 15 percent, resulted in acceptable baked products. The cookies prepared with rice bran were of improved its nutritional value

There for it is suggested that stabilization of rice bran must be used in baking industry to provide value added products to consumer. Hence it is inferred from these findings that supplementing cookies with OSRB from $10-15 \%$ is more suitable for production of rice bran supplemented cookies.
\end{abstract}

Key words: Rice, rice bran, Microwave stabilized rice bran, Oven heat stabilized rice bran.

\section{INTRODUCTION}

Rice (Oryza sativa L.) is one of the most popular grain crops of the world, the staple grain of over half the world's population. It is generally considered a semi aquatic, annual, grass plant. Cultivars of the two cultivated species, O. sativaL. and $O$. glaberrima, can grow in a wide range of water-soil regimes, from deeply flooded land to dry, hilly slopes.. This grain is grown in over 100 countries on every continent except Antarctica, extending from $53^{\circ}$ north to $40^{\circ}$ south and from sea level to an altitude of $3,000 \mathrm{~m}$. However, $O$. glaberrima is grown only in Africa and only on a limited scale. Production practices for rice range from very primitive to highly mechanize.

The bran, which is a major product during rice milling process is about $1 / 10$ of the weight of the grain. This milling by-product is reported to be high in natural vitamins and minerals, especially vitamin E.

About $65 \%$ of the nutritional value of the rice kernel is dampt away in the rice bran. Rice bran enjoys to be one of the highest nutrient-dense naturally food available but it is unused of food resource. This is due to an enzyme that causes rancid and deterioration within hours of production, turning it to be unsuitable for human consumption. Most of rice bran turns to be used as animal feed. Accordingly, the most nutrient-dense part of the rice grain never makes its way to our table.
Gamma Oryzanol from rice bran oil contains stronger antioxidant property and promote the health problem such as: reducing blood cholesterol, increasing testosterone levels, and treating menopausal disorder.Total cholesterol levels in animals decreased till 40\%, and LDL levels decreased up to $60 \%$, after their diets included a concentrated form of Vitamin E extracted from rice bran. (kahlan et al 1989).

Also, it has been cited that due to its high level of active components, rice bran oil is considered to be very health promoting. g-Oryzanol and phytosterols have the effect to dicrease blood cholesterol as well asits absorption. Tocotrienols and g-oryzanol are known as powerful antioxidants, and this is associated with the prevention of cardiovascular diseases and some cancers. (kisten et al 1990).

Many methods where conducted to stabilize the bran and use them as a main source of nutrients (Young, 2000; Jiaxun, 2001).The baking is a developing industry, which is growing in size. Among bakery products especially cookies are liked by the all age groups especially very small and very old people. The functional food which is formulated from supplemented cookies ensure to overcome the malnutrition problem among the various segments of old population. Keeping in mind the above facts, this research was designed to prepare cookies from stabilized rice bran that could prevent many diseases and evaluate health properties by consuming a quality of cookies. The main objectives of this study were to evaluate the 
suitability of (MSRB) and(OSRB) supplemented cookies and to prepare and analyze rice bran supplemented cookies for their chemical, physical and sensory evaluation.

\section{MATERIALS AND METHODS:}

Collection of raw materials: Freshly milled rice bran was collected from Rice Technology Training Center, Alexandria Egypt. Rice bran was stabilized to inactivate the lipase and lipoxygenase enzymes and denature trypsin inhibitors. To achieve this, the rice bran was subjected to the following heat treatments.

Stabilization of rice bran: Freshly milled bran was treated with heat by placing it in a Microwave for 3 minutes to get Microwave Stabilized Rice Bran (MSRB). Whereas to prepare Oven Stabilized Rice Bran (OSRB), the rice bran was placed in an oven, maintained at a temperature of $120{ }^{\circ} \mathrm{C}$ for 10 to15 seconds. The treated and stabilized rice bran was packed in plastic top zipped bags and stored in dark cold store at $10{ }^{\circ} \mathrm{C}$ according to the previous method given by Iqbal (2005).

Preparation of cookies: The cookies were baked by adding rice bran in wheat flourat $0,5,10,15$ and $25 \%$ level as given in Table 1 according to the procedure described by McWatters et al. (2003) with slight modifications. The basic ingredients used were $360 \mathrm{~g}$ of flour blend, $100 \mathrm{ml}$ rice bran oil, $200 \mathrm{~g}$ of granulated sugar, $20 \mathrm{~g}$ of beaten whole egg, $3 \mathrm{~g}$ of salt, and $1.5 \mathrm{~g}$ of baking soda. All the dry components were weighed and thoroughly mixed in a food processor for 5 minutes. The oil was added and rubbed-in until uniform. The egg was added to the dough thoroughly and replaced in a mixer for $5 \mathrm{~min}$. The dough was rolled thinly on a sheeting butter paper to a uniform thickness (10.0 $\mathrm{mm}$ ) and shaped out using a round form with a diameter of $40.0 \mathrm{~mm}$. The forming of the dough into pieces and were baked on tefal pans at $180^{\circ} \mathrm{C}$ for $15 \mathrm{~min}$ in a baking oven. The baked cookies were placed to be cooled until room temperature $\left(28 \pm 2^{\circ} \mathrm{C}\right)$ and packed in a polyethylene zip bags.

Table 1: Levels of Bran used in the study

\begin{tabular}{ccc}
\hline Levels & Wheat Flour (\%) & Rice bran (\%) \\
\hline L0 & 100 & 0 \\
\hline L1 & 95 & 5 \\
\hline L2 & 90 & 10 \\
\hline L3 & 85 & 15 \\
\hline L4 & 75 & 25 \\
\hline
\end{tabular}

Chemical analysis: The cookies were baked by adding rice bran in wheat flour at $0,5,10,15$ and 25 percent level as described in the AACC (2000).

Moisture: The moisture content was determined as per procedure given in AACC (2000) method No. 44-15A.
Crude protein: The nitrogen content in sample was determined by Kjeldahl's method as described in AACC method No. 46-10.

Crude fat: The crude fat (ether extract) was determined by using Soxtec System HT2,extraction unit of Tecator, Hoganas, Sweden by following the instructions provided in the manufacturer's manual and the procedure described in AACC (2000) method No. 30-10.

Mineral determination: The minerals $\mathrm{Fe}, \mathrm{Ca}, \mathrm{Mg}$, $\mathrm{Mn}$, and $\mathrm{Zn}$ were determined after wet digestion by using Atomic Absorption Spectrophotometer (Model Varian Spectra AA 240) in the Department of Food Chemistry and Pharmacy University of Friedrich Alexander Erlangen - Nurnberg ,Germany according to AACC (2000)method No. 40-70.

Physical evaluation: Physical characteristics like width, thickness and spread factor were determined according to the AACC (2000) Method No. 10-53.

Sensory evaluation: A panel of five judges selected from the residence of Ahmos Geriatric House evaluated the cookies for their sensory parameters like color, flavor, taste, texture and overall acceptability according to the method described by Larmond (1977) using10 points scale with following individual scores: liked extremely10 , liked very much-9, liked moderately- 8 , liked slightly -7 , neither liked nor disliked-6, disliked slightly-5, disliked moderately-4, disliked very much-3 and disliked extremely-2, very bad -1 , to find out the most suitable composition of cookies

Statistical analysis: The data obtained was analyzed statistically to test the changes indifferent parameters of the study by using analysis of variance (Steel et al., 1997) and DMR testfor means separation by SAS Software.

\section{RESULTS AND DISCUSSIONS}

Chemical analysis of rice bran: Rice bran obtained after stabilization was chemically analyzed (Table 2). The analysis revealed that moisture, protein, and fat were found to be 18 to $18.17 \%, 13.25$ to 12.60 and 16.67 to $16.93 \%$, respectively between MSRB and OSRB respectively.

Mineral analysis showed that MSRB contained Fe 63.24 ppm, Mn 16.53 ppm, Zn 24.44 ppm, Ca $244.88 \mathrm{ppm}$ and $\mathrm{Mg} 270.12 \mathrm{ppm}$ with no significant difference to OSRB. Numerous studies conducted on various aspects of rice bran showed that it contains 13.2 to 17.3 percent protein, fat 11 to 18 percent, fiber 9.5 to 13.2 percent, and 9.2 to 12.2 percent total ash on dry basis (Houston. and Kohler, 1970; Pomeranz and Oryl, 1982; Holland et al., 1991).

Chemical analysis of cookies: Rice bran supplemented cookies were chemically analyzed for their composition as described in Table 3. 
Table 2: Chemical analysis of rice bran

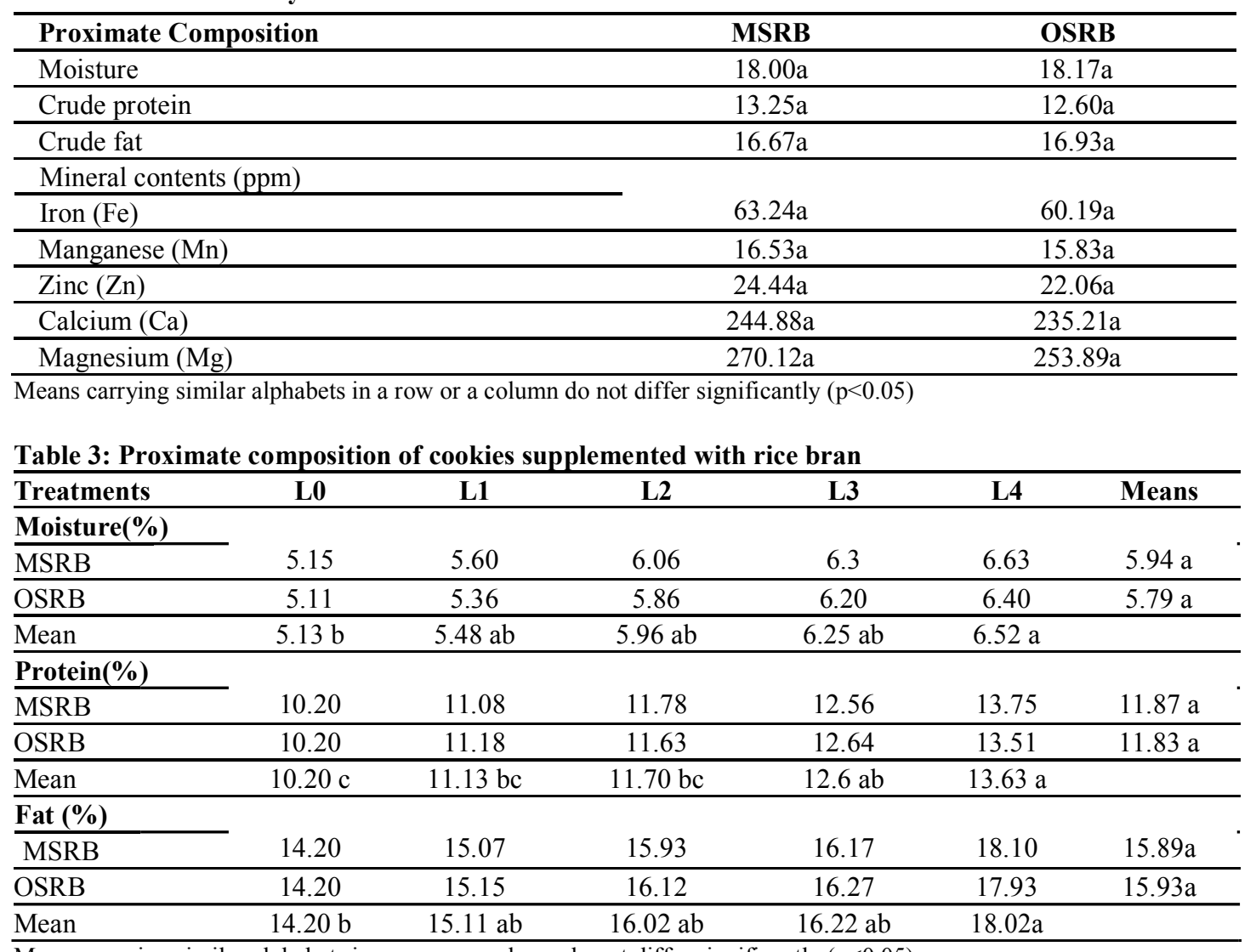

Means carrying similar alphabets in a row or a column do not differ significantly $(\mathrm{p}<0.05)$

Cookies prepared with MSRB were not significantly different to OSRB for proximate composition and mineral content. The chemical analysis of cookies supplemented with different levels of rice bran manifested that significantly highest moisture content were found in L4 (6.52 $\%)$ followed by L3 (6.25\%) and significantly lowest were found in L0 (5.13 percent) non supplemented cookies (Table 3). As rice bran contains more cellulose and other non-starch polysaccharides that hold moisture several times higher to its weight, so with the increase of rice bran level there was an increase in moisture content of cookies. Protein content was also affected significantly due to addition of different levels of rice bran. The highest protein content (13.63 percent) was found in L4 followed by 12.6 , $11.70,11.13$, and 10.20 percent for L3, L2, L1, and L0, respectively. The mean values for fat were $14.20,15.11,16.02,16.22$, and 18.02percent for L0, L1, L2, L3, and L4, respectively. The increase in protein content may be ascribed to the higher protein and fat content of rice bran. With the increase in level of rice bran, protein and fat content of cookies increased accordingly. Mineral contents of cookies substituted with rice bran are shown in the Table 4. Significantly highest Iron content (41.55ppm) was found in L4 followed by $38.95,36.30,32.92$ and $29.75 \mathrm{ppm}$ in L3, L2, L1, and L0, respectively. Mean values showed that highest $\mathrm{Zn}$ content was found to be $12.28 \mathrm{ppm}$ for L4 followed by $11.16,10.32,9.35$ and 7.89 for L3, $\mathrm{L} 2$, L1, and $\mathrm{L} 0$, respectively. The lowest $\mathrm{Zn}$ content was observed in non-supplemented cookies. Zinc content increased significantly with increasing the level of rice bran. It is obvious from chemical assay of rice bran (Table 2) that it is a very good source of $\mathrm{Zn}(24.44 \mathrm{ppm})$. Highest Manganese content (8.08 ppm) was found for L4 followed by $7.05,6.18,5.18$ and $4.36 \mathrm{ppm}$ for L3, L2, L1 and L0 respectively. Highest calcium content $(71.51 \mathrm{ppm})$ was found for L4 followed by $65.22,54.45,39.18$ and 25.84 ppm for L3, L2, L1, and $\mathrm{L} 0$, respectively. More pronounced increase for $\mathrm{Ca}$ content in case of L4 (71.51 ppm) may be attributed to the higher $\mathrm{Ca}$ content of the rice bran, as the minerals are occurred in the bran portion of grains. Results expressed that highest $\mathrm{Mg}$ content (99.04 ppm) was found for L4 followed by 83.84, 70.7, 59.93 and $46.78 \mathrm{ppm}$ for L3,L2,L1, and L0, respectively. The lowest $\mathrm{Mg}$ content was witnessed in case of $\mathrm{L} 0 . \mathrm{Mg}$ increased by increasing level of 
rice bran. These results are the same with the findings of Sharif et al., (2009).

Sensory evaluation of cookies: Cookies prepared with MSRB got significantly higher scores as compared to OSRB cookies except in texture. When the effect of substitution of different levels of rice bran studied the cookies prepared with wheat flour got the highest scores for color, texture, taste, flavor and overallacceptability followed by L1, L2, L3 and L4 respectively (Table 5). Sensory evaluation of cookies emphasized that scores for color of cookies decreased significantly with increase in the level of rice bran. However the decrease was insignificant at 10 percent level of supplementation.The highest acceptability score of the supplemented cookies were given to the 15 percent level of substitution as compared to other levels of supplementations. These results are in agreement with the findings of Sharma and Chauhan (2002). Sudha et al. (2007) reported that progressive increase in supplementation level of rice bran produced dark cookies. These results are also in conformity with the findings of Sharma and Chauhan (2002) who reported that flavour response decreased with increase in the level of bran in the cookies and 20 percent replacement of flour with wheat bran. Hence it is concluded from the results that supplementation of OSRB at 10 percent is the most acceptable level and stabilization treatment for producing rice bran supplemented cookies.

Physical evaluation of cookies: The mean values for width of cookies (Table 6) showed a decreasing trend with the proportionate increase of rice bran supplementation. Cookies prepared with MSRB got no significant difference when compared to OSRB supplemented cookies for physical attributes. The results elucidated that $\mathrm{L} 0$ (cookies without rice bran) exhibited maximum width $52.27 \mathrm{~mm}$, followed by L1 $(52.19 \mathrm{~mm})$ and L2 $(50.84 \mathrm{~mm})$ while minimum width $(49.21 \mathrm{~mm})$ was witnessed in L4 (cookies with 20 percent rice bran). The results for thickness of cookies (Table 6) revealed increasing trend with proportionate increase of rice bran in commercial straight grade flour. The results explicated that L4 (cookies with 20 percent rice bran) exhibited maximum thickness $(10.53 \mathrm{~mm})$ followed by L3 $(10.22 \mathrm{~mm})$ and L2 $(9.88 \mathrm{~mm})$ while minimum thickness $(9.30$ $\mathrm{mm}$ ) was measured in L0(cookies with 0 percent rice bran). There was a decreasing trend in the spread ratio of cookies with the proportionate increase of supplementation. The spread factor of cookies, prepared from different treatments ranged from 49.60-55.25. The maximum value (55.25) for spread ratio was observed in L0 (cookies with 0 percent rice bran) whereas minimum value (49.60) in cookies prepared from 20 percent rice bran supplementation. Rice bran replacement up to 1020 percent was found to be appropriate in cookies. These results are in accordance with the findings of Sharif et al. (2009) who reported that spread factor of rice bran supplemented cookies decreased with the increasing level of rice bran. Sekhon et al.(1997) also reported that cookie spread progressively decreased with an increase in the level of both laboratory and commercially defatted brans.

Table 4: Minerals content ofcookies supplemented with rice bran

\begin{tabular}{|c|c|c|c|c|c|c|}
\hline Treatment & $\mathbf{L O}$ & L1 & $\mathbf{L 2}$ & $\mathbf{L 3}$ & L4 & Means \\
\hline \multicolumn{7}{|c|}{ Iron (mg/Kg) } \\
\hline MSRB & 29.75 & 33.16 & 37.23 & 40.32 & 43.02 & 36.80 \\
\hline OSRB & 29.75 & 32.69 & 35.36 & 37.08 & 40.08 & 35.00 \\
\hline Mean & $29.75 d$ & $32.92 \mathrm{~cd}$ & $36.30 \mathrm{bc}$ & $38.95 \mathrm{ab}$ & $41.55 \mathrm{a}$ & \\
\hline \multicolumn{7}{|c|}{ Manganese(mg/Kg) } \\
\hline MSRB & 4.36 & 5.19 & 6.22 & 7.09 & 8.06 & $6.18 \mathrm{a}$ \\
\hline OSRB & 4.36 & 5.16 & 6.14 & 7.00 & 8.10 & $6.15 \mathrm{a}$ \\
\hline Mean & $4.36 \mathrm{~d}$ & $5.18 \mathrm{~cd}$ & $6.18 \mathrm{bc}$ & $7.05 \mathrm{ab}$ & $8.08 \mathrm{a}$ & \\
\hline \multicolumn{7}{|c|}{ Zinc (mg/Kg) } \\
\hline MSRB & 7.89 & 9.24 & 9.91 & 11.39 & 12.26 & 10.14 \\
\hline OSRB & 7.89 & 9.46 & 10.73 & 10.92 & 12.30 & 10.26 \\
\hline Mean & $7.89 \mathrm{~d}$ & $9.35 \mathrm{c}$ & $10.32 \mathrm{~b}$ & $11.16 \mathrm{~b}$ & $12.28 \mathrm{a}$ & \\
\hline \multicolumn{7}{|c|}{ Calcium(mg/Kg) } \\
\hline MSRB & 25.84 & 39.92 & 55.61 & 65.57 & 70.96 & 51.58 \\
\hline OSRB & 25.84 & 38.43 & 53.29 & 64.87 & 72.05 & 50.90 \\
\hline Mean & $25.84 \mathrm{e}$ & $39.18 \mathrm{~d}$ & $54.45 \mathrm{c}$ & $65.22 \mathrm{~b}$ & $71.51 \mathrm{a}$ & \\
\hline \multicolumn{7}{|c|}{ Magnesium(mg/Kg) } \\
\hline MSRB & 46.780 & 60.64 & 70.29 & 84.43 & 100.11 & 72.45 \\
\hline OSRB & 46.780 & 59.22 & 71.11 & 83.26 & 97.96 & 71.67 \\
\hline Mean & $46.780 \mathrm{e}$ & $59.93 \mathrm{~d}$ & $70.7 \mathrm{c}$ & $83.84 \mathrm{~b}$ & $99.04 \mathrm{a}$ & \\
\hline
\end{tabular}


Table 5: The sensory evaluation of cookies supplemented with rice bran

\begin{tabular}{|c|c|c|c|c|c|c|}
\hline Treatment & LO & L1 & L2 & $\mathbf{L 3}$ & L4 & Means \\
\hline \multicolumn{7}{|l|}{ Color } \\
\hline MSRB & 7.000 & 6.200 & 6.000 & 5.533 & 5.033 & 5.953 \\
\hline OSRB & 7.000 & 6.167 & 6.000 & 5.200 & 4.267 & $5.727 \mathrm{~b}$ \\
\hline Mean & $7.000 \mathrm{a}$ & $6.184 \mathrm{~b}$ & $6.000 \mathrm{~b}$ & $5.367 \mathrm{c}$ & $4.650 \mathrm{~d}$ & \\
\hline \multicolumn{7}{|l|}{ Texture } \\
\hline MSRB & 6.000 & 5.500 & 5.767 & 6.533 & 4.933 & $5.747 \mathrm{a}$ \\
\hline OSRB & 6.000 & 6.200 & 5.533 & 4.533 & 4.267 & $5.307 \mathrm{a}$ \\
\hline Mean & $6.000 \mathrm{a}$ & $5.850 \mathrm{a}$ & $5.650 \mathrm{a}$ & $5.533 \mathrm{ab}$ & $4.599 \mathrm{~b}$ & \\
\hline \multicolumn{7}{|l|}{ Taste } \\
\hline MSRB & 5.976 & 5.200 & 5.967 & 5.100 & 4.210 & $5.291 \mathrm{a}$ \\
\hline OSRB & 5.833 & 5.500 & 4.100 & 3.867 & 4.267 & $5.053 \mathrm{~b}$ \\
\hline Mean & $5.967 \mathrm{ab}$ & $5.517 \mathrm{a}$ & $5.734 \mathrm{ab}$ & $4.600 \mathrm{~b}$ & $4.039 \mathrm{~b}$ & \\
\hline \multicolumn{7}{|l|}{ Flavour } \\
\hline MSRB & 6.567 & 6.000 & 5.800 & 5.867 & 4.267 & $5.499 \mathrm{a}$ \\
\hline OSRB & 6.567 & 5.500 & 5.767 & 4.283 & 4.100 & $5.043 \mathrm{~b}$ \\
\hline Mean & $6.567 \mathrm{a}$ & $5.750 \mathrm{~b}$ & $5.784 \mathrm{~b}$ & $5.075 \mathrm{c}$ & $4.184 \mathrm{~d}$ & \\
\hline \multicolumn{7}{|c|}{ Overall acceptability } \\
\hline MSRB & 6.967 & 6.200 & 6.200 & 6.000 & 4.500 & $5.933 \mathrm{a}$ \\
\hline OSRB & 6.967 & 6.133 & 6.033 & 4.000 & 4.300 & $5.293 \mathrm{~b}$ \\
\hline Mean & $6.967 \mathrm{a}$ & $6.167 \mathrm{~b}$ & $6.117 \mathrm{~b}$ & $5.000 \mathrm{c}$ & $4.400 \mathrm{~d}$ & . \\
\hline
\end{tabular}

Means carrying similar alphabets in a row or a column do not differsignificantly $(\mathrm{p}<0.05$

Table 6: Effect of rice bran substitution on physical properties of cookies

\begin{tabular}{|c|c|c|c|c|c|c|}
\hline Treatments & $\mathbf{L 0}$ & L1 & $\mathbf{L 2}$ & $\mathbf{L 3}$ & $\mathbf{L 4}$ & Means \\
\hline \multicolumn{7}{|c|}{ Thickness (mm) } \\
\hline MSRB & 9.30 & 9.91 & 9.69 & 10.24 & 10.45 & $50.78 \mathrm{a}$ \\
\hline OSRB & 9.30 & 9.91 & 10.07 & 10.20 & 10.60 & $50.91 \mathrm{a}$ \\
\hline Mean & $9.30 \mathrm{~b}$ & $9.91 \mathrm{ab}$ & $9.88 \mathrm{ab}$ & $10.22 \mathrm{a}$ & $10.53 \mathrm{a}$ & \\
\hline \multicolumn{7}{|l|}{ Width } \\
\hline \multicolumn{7}{|l|}{$(\mathrm{mm})$} \\
\hline MSRB & 52.27 & 51.88 & 50.51 & 49.81 & 49.46 & $50.79 \mathrm{a}$ \\
\hline OSRB & 52.27 & 52.49 & 51.17 & 49.46 & 48.95 & $50.91 \mathrm{a}$ \\
\hline Mean & $52.27 \mathrm{a}$ & $52.19 \mathrm{a}$ & $50.84 \mathrm{~b}$ & $49.72 \mathrm{c}$ & $49.21 \mathrm{c}$ & \\
\hline \multicolumn{7}{|c|}{ Spread Factor } \\
\hline MSRB & 55.25 & 54.15 & 52.49 & 50.91 & 50.53 & $52.64 \mathrm{a}$ \\
\hline OSRB & 55.25 & 54.03 & 52.87 & 50.20 & 48.66 & $52.24 \mathrm{a}$ \\
\hline Mean & $55.25 \mathrm{a}$ & $54.09 \mathrm{~b}$ & $52.68 \mathrm{c}$ & $50.56 \mathrm{~d}$ & $49.60 \mathrm{e}$ & . \\
\hline
\end{tabular}

Means carrying similar alphabets in a row or a column do not differ significantly $(\mathrm{p}<0.05)$;

\section{CONCLUSION}

In accordance it could be concluded that small to moderate supplemented levels of rice bran, especially in the range of 10 to 15 percent, results in acceptable baked products. The cookies supplemented with rice bran enhanced its nutritional value therefore it is suggested that stabilized rice bran must be used in baking industry to provide value added products to consumer. Hence it is inferred from the results that supplementation of OSRB at 10 to 15 percent is more ends to an acceptable and nutritional product of rice bran supplemented cookies.

\section{REFERENCES}

AACC. 2000. Approved Methods of American Association of Cereal Chemists. Am. Assoc. Cereal Chem. Inc., St. Paul., Minnesota, USA

Bor SL.1991 Rice oil in rice utilization. Van Nostrand Reinhold New York,; 295-311.

Carroll, L.E. 1990. Functional properties and applications of stabilized rice bran in bakery products. Food Tech. 44:74-76. 
Champagne E, Horn SR.1992 Stability of ethanolextracted brown rice to hydrolytic and oxidative deterioration. Journal of Food Science.; 57: 433436.

Chang S.C., C.T.Sun, T.Y.Liu.1980. Development of rice bran oil, Food industry. Research and Development Institute Research Report, Taiwan.; 172.

Desikachar H.S.R. 1977. Preservation of by-Products of rice milling. In: Proc. Rice By-Product. Utilization.; p. 1-32.

GOP. 2009. Economic Survey 2008-09. Government of Pakistan, Economic Advisor Wing, Finance Division, Islamabad, Pakistan

Holland, B, A.A. Welch, I.D. Unwin, D.H. Buss, A.A. Paul and D.A.T. Southgate. 1991. The Composition of Foods. 5th Ed. Roy.Soc. Chem. and Maff, Cambridge.

Houston, D.F. and G.O. Kohler. 1970. Nutritional properties of rice. National Academy of Sciences, Washington D.C.

Iqbal, S., M.I. Bhanger and F. Anwar. 2005. Antioxidant properties and components of some commercially available varieties of rice bran in Pakistan. Food Chemistry 93:265-272.

Huang CS, Chang SC. 1983. Treatment of rice bran by extrusion- cooking for oil extraction- An experiment prior to large scale demonstration and extension. Food Industry Research and Development Institute Research.Report 293. Taiwan.

Hung Y.C. and R.D. Philips. 2003. Physical and sensory characteristics of sugar cookies containing mixtures of wheat, fonio (Digitariaexilis) and cowpea (Vignaunguiculata) flours. Int. J. Food Sci. Tech. 38:403-410

Jiaxun, T. 2001. Method of stabilization of rice bran by acid treatment and composition of the same.United States Patent. No. 6245377 BI, June, 12, 2001, http://www.freepatentsonline.com/6245377.pdf Accessed May, 30, 2010.

Kahlon TS, Saunders RM, Chow FI, Chiu MC, Betschart AA.1971 Effect of rice bran and oat bran on plasma cholesterol in hamsters. Cereal Food World.1989; 34: 768.

Kopeikovskii VM, Arutyunyan NS, Proskurina VI.Chemical composition and mineral content of rice bran

Kestin, M., R. Moss, P.M. Clifton and P.J. Nestle. 1990. Comparative effect of three brans on plasma lipids, blood pressure and glucose metabolism in mildly hypercholesterolemic men. Am. J. Clin. Nutr. 52: 661-666.

Kousik HM.1994. Rice Bran and rice bran oil may lower heart disease risk by decreasing cholesterol synthesis in the body. Journal of the American Oil Chemists' Society.; 30: 538.

Larmond, E. 1977. Laboratory methods of sensory evaluation of food. Research Branch, Canada, Dept. of Agri. Publication. p.44.
Lynn, L. 1969. Edible rice bran foods. Cereal Chem. 46:154-172.

McWatters, K.H., J.B. Ouedraogo, A.V.A. Resurrection,

Pomeranz, Y. and R.L. Oryl. 1982. Rice processing and utilization. CRC Handbook of Processing and Utilization in Agriculture,Vol.II. CRC Press, West Palm Beach,FL.

Sekhon, K.S., S.S. Dhillon, N. Singh and B. Singh. 1997. Functional suitability of commercially milled rice bran in India for use in different food products. Plant Foods Hum.Nutr. 50:127-140.

Sharma, H.R. and G.S. Chauhan. 2002. Effect of stabilized rice bran fenugreek blends on the quality of breads and cookies. J. Food Sci. Nutr. 39:225-233.

Sharif, M.K., M.S. Butt, F.M. Anjum and H. Nawaz. 2009. Preparation of fiber and mineral enriched defatted rice bran supplemented cookies. Pak. J. Nutr. 8:571-577.

Steel, R.G.D., J.H. Torrie and D. Dickey. 1997. Principles and Procedures of Statistics. A biometrical approach, 3rd Ed. McGraw Hill Book Company Inc., New York.

Sudha, M.L., R. Vetrimani and K. Leelavathi. 2007. Influence of fiber from different cereals on the rheological characteristics of wheat flour dough and on biscuit quality. J. Food Chem. 100:13651370.

Warren, B.E. and D.J. Farrell. 1990. The nutritive value of full fat and defatted Australian rice bran and chemical composition. Anim. Feed Sci. Tech. 27:219-223.

Young, S.K. 2000. Effect of heat treatment on physiochemical properties of defatted rice bran.Food Sci. Biotechnol. 8:143-148.

Tantawi, A.B. 2002. The Annual Report of the National Campaign of Rice.Ministry of Agriculture Academy of Science, Research \& Technology.

Orthoefer F.T.,Y.H.Hui 1996. Bailey Industrial Oil and Fat Products.5th edition.Wiley and Sons, Inc. New York;: 2.

Ledesma L.,S.Fuertes, E. Barrios, A.Rodriguez, H.Zumbado,G.Hermandez D.Castillo $\mathbf{1 9 9 0}$ Nutritive value of protein concentrate from rice bran Ciencia -y- Tecnia- en- la Agricultura, Aoraz.(C.F. Rice Abstracts 9301-N528666. 1990; 13:1-2, 7-14.

Linda E, A. Carroll. 1990Functional properties and applications of stabilized rice bran in bakery product. Journal of Food Technology.; 74-77.

Loeb JR,N.G.Morris,F.G.Dollear. 1994. Rice bran oil. Longman;.

Martin J.D., G. Samuel, S. Gladness, V. Latit,H. John.1993 Optimizing rice bran stabilization by extousion cooking, Louisiana Agriculture.; 36:13-5. 


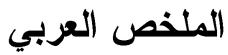

\section{استخدام رجيع الأرز كغذاء علاجى لكبار السن فى مصر}

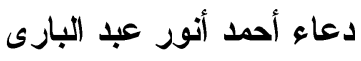 \\ مركز تدريب تكنولوجيا الأرز - معهد بحوث المحاصيل الحقلية- مركز البحوث الزراعية
}

تعتبر الرجيعة منتج ثانوى من منتجات صناعة ضرب الأرز وتمثل / / إمن الحبة وتعتبر الرجيعة هى الطبقة

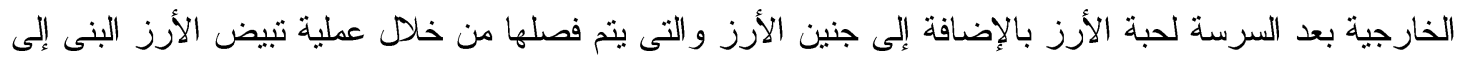

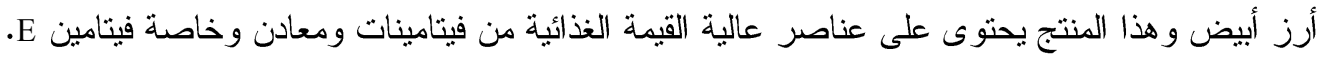

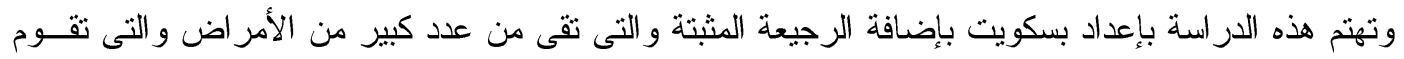

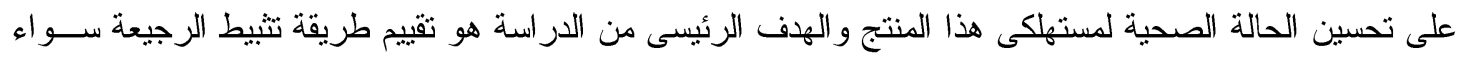

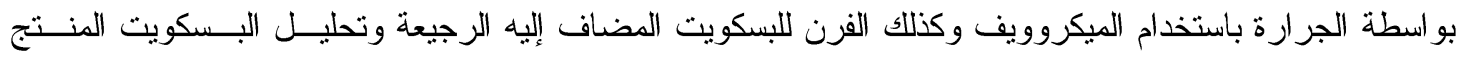

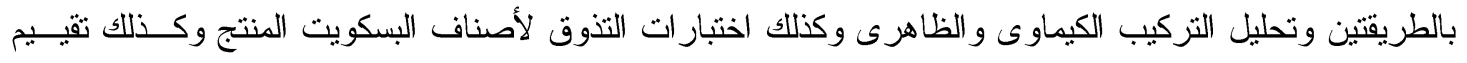

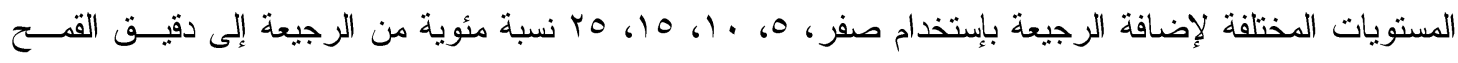

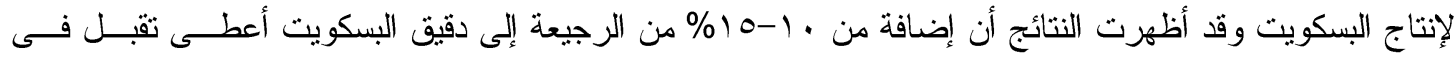

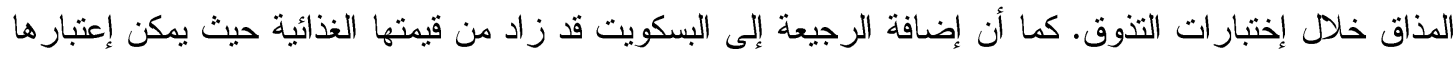

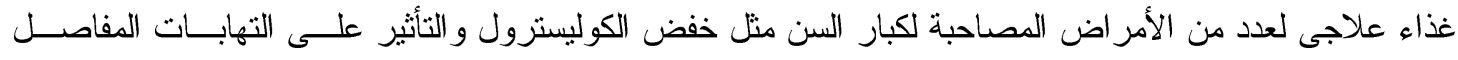

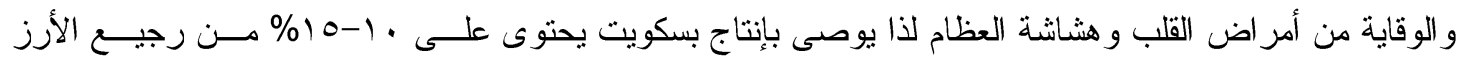

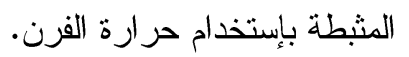

